Supporting Information:

\title{
Photo-isomerization of Spiropyran for driving a Molecular Shuttle
}

Weidong Zhou, Dugang Chen, Junbo Li, Jialiang Xu, Jing Lv, Huibiao Liu, Yuliang $\mathrm{Li}^{*}$

National Laboratory for Molecular Sciences, Key Laboratory of Organic Solids, Institute of Chemistry, Chinese Academy of Sciences, Beiijng, 100080, P. R. China ylli@iccas.ac.cn

Table of contents:

§1. Materials.

§2.Measurements.

§3. Synthesis Route

§4. Synthesis and characterization data of all compounds

§5. Kinetic Studies

§6. Reference. 


\section{§1. Materials.}

Unless stated otherwise, all reagents and anhydrous solvents were purchased for Aldrich Chemicals and used without further purification.

\section{§2. Measurements}

Columnchromatography (CC): $\mathrm{SiO}_{2}$ (200-300 meshes). TLC glass plates coated with $\mathrm{SiO}_{2} \mathrm{~F} 254$ were visualized by UV light. ${ }^{1} \mathrm{H}$ and ${ }^{13} \mathrm{C}$ NMR spectra were recorded on a Bruker AV 400 or 600 instruments, at a constant temperature of $25^{\circ} \mathrm{C}$. Chemical shifts are reported in parts per million from low to high field and referenced to TMS. MALDI-TOF mass spectrometric measurements were performed on Bruker Biflex III MALDI-TOF. UV/ vis spectra were measured on a Hitachi U-3010 spectrometer. Fluorescence excitation and emission spectra were recorded using a Hitachi F-4500 FL fluorimeter at a constant temperature of $25^{\circ} \mathrm{C}$. 


\section{§3. Synthesis Route}

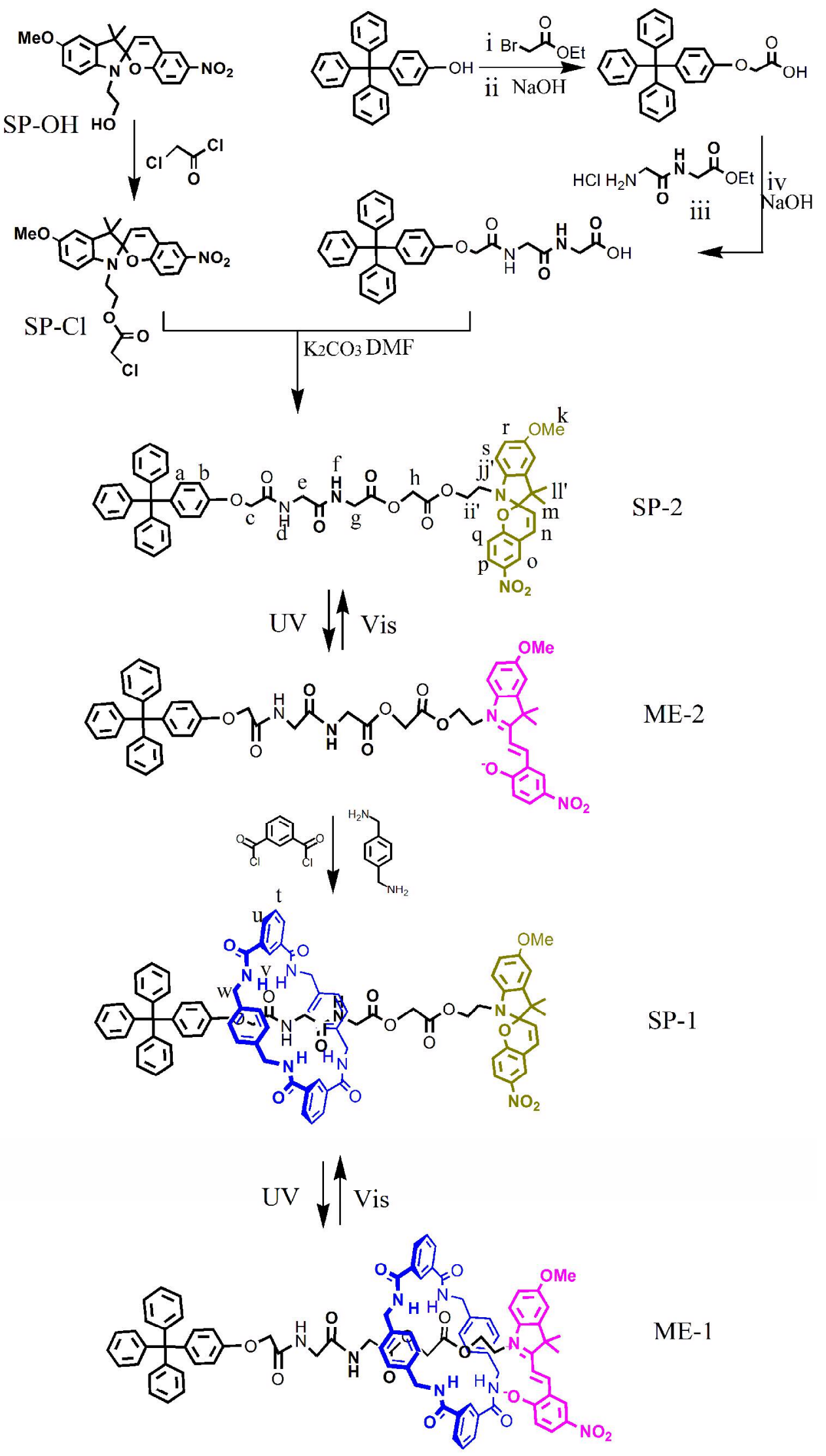




\section{§4. Synthesis and characterization data of all compounds}

SPN-OH A solution of 6-methoxy-3a,4,4-trimethyloxazolidino[3,2-a]indoline (932mg, $4 \mathrm{mmol}$ ) and 2-hydroxy-5-nitrobenzaldhyde (735mg, $4.4 \mathrm{mmol})$ in alcohol $(15 \mathrm{~mL})$ was heated for $3 \mathrm{~h}$ under reflux and nitrogen. After cooling down to room temperature, the mixture was filtered. The residual purple solid was washed with $\mathrm{EtOH}(10 \times 3)$ and dried to afford ME $(1.2 \mathrm{~g}, 81 \%) .{ }^{1} \mathrm{H} \operatorname{NMR}\left(\mathrm{CDCl}_{3}\right) \delta 8.007(\mathrm{~m}, 2 \mathrm{H}), 6.898(\mathrm{~d}, 1 \mathrm{H}$, $J=10.344 \mathrm{~Hz}), 6.756(\mathrm{~m}, 3 \mathrm{H}), 6.577(\mathrm{~d}, 1 \mathrm{H}, J=8.08 \mathrm{~Hz}), 5.872(\mathrm{~d}, 1 \mathrm{H}, J=10.35 \mathrm{~Hz})$, 3.79(s, 3H), 3.84-3.69 (m, 2H), 3.40(m, 1H), 3.28(m, 1H), 1.27(s, 3H), 1.239(s, 3H). ${ }^{13} \mathrm{C} \mathrm{NMR}\left(\mathrm{CDCl}_{3}\right) \delta 158.39,153.31,140.08,136.48,130.92,127.18,124.90,121.718$, 120.88, 117.54, 114.466, 110.455, 108.778, 106.24, 106.03, 66.91, 59.85, 54.93, 52.39, 51.91, 45.475, 24.768, 24.566, 18.914. MS (EI): 381( $\left.\mathrm{M}^{+}\right)$

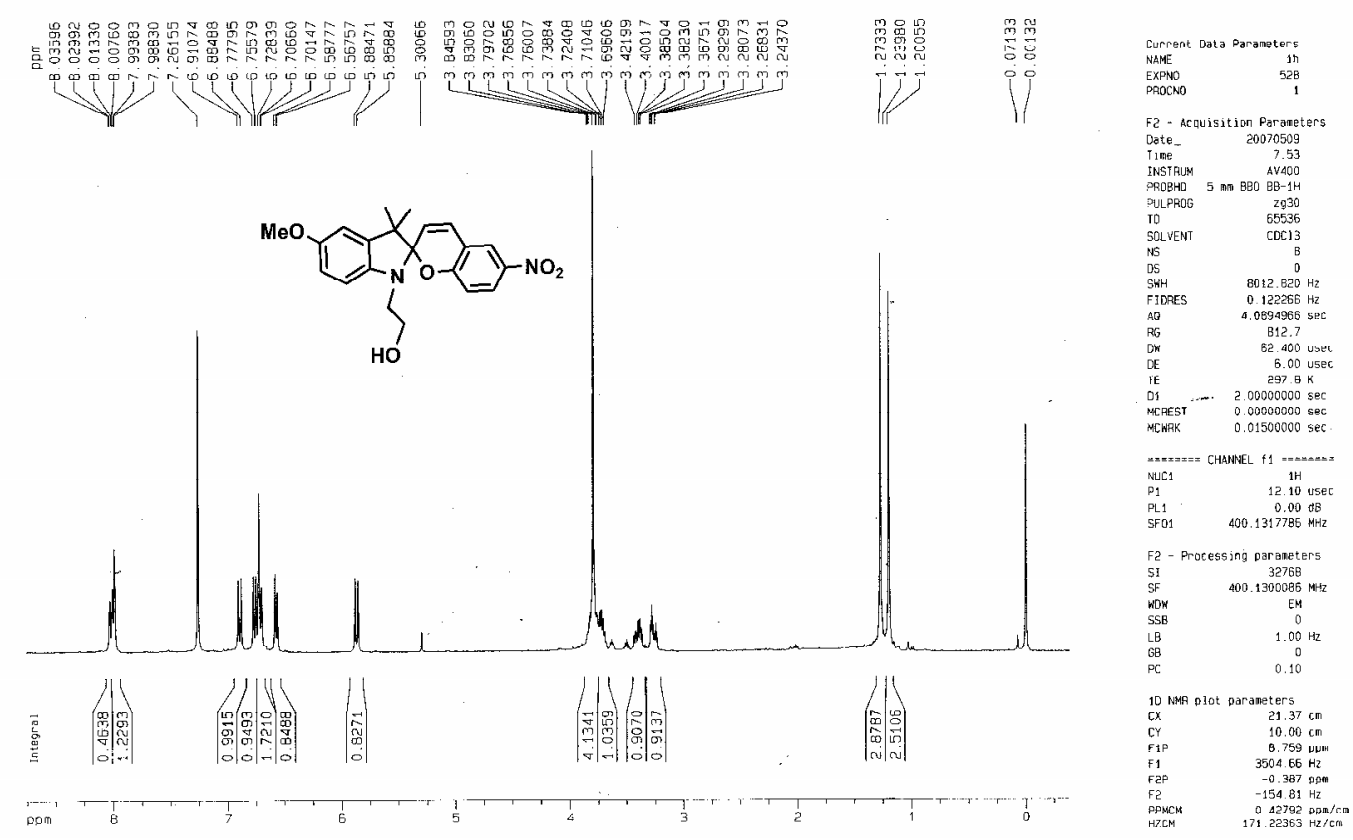




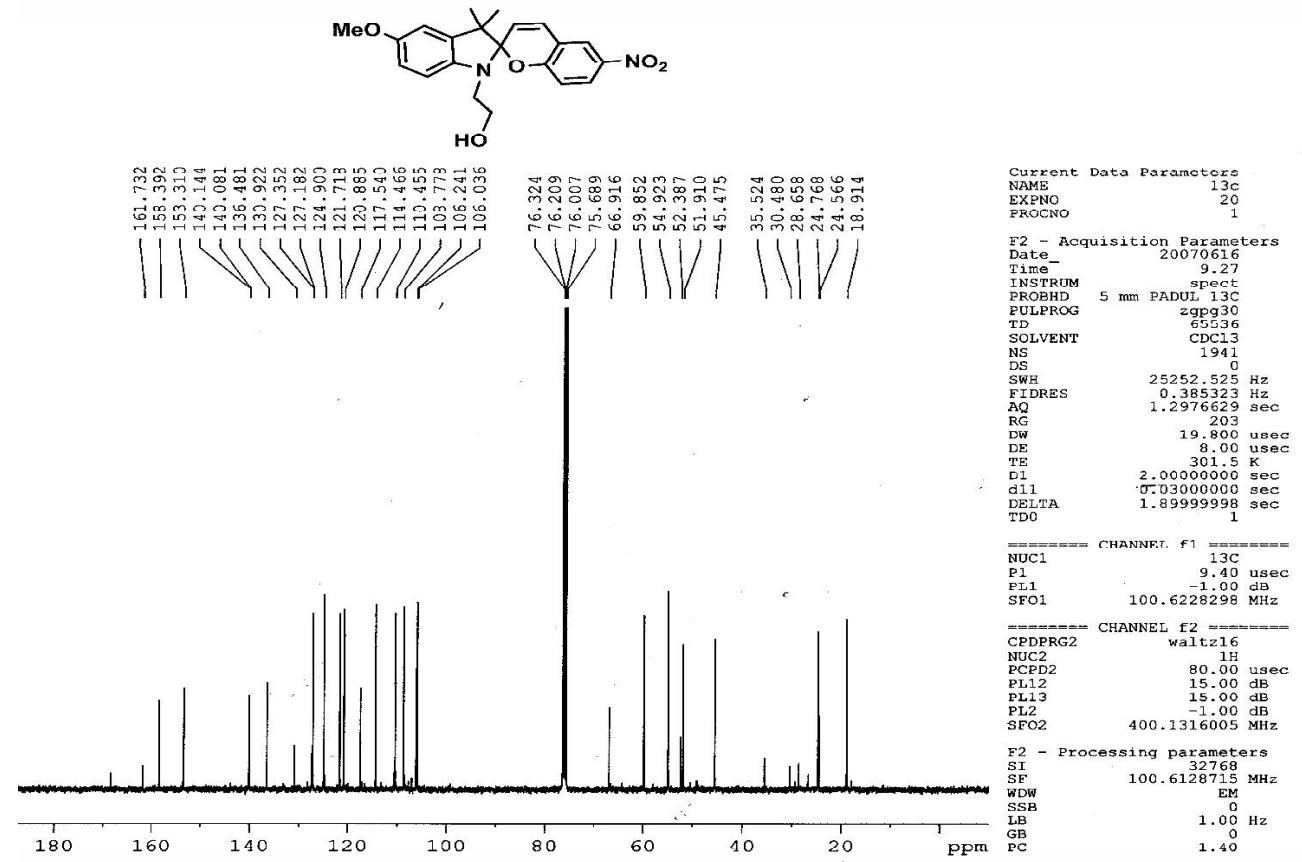




\section{SPN-CI}

2-chloroacetyl chloride $(0.67 \mathrm{~g}, 6 \mathrm{mmol})$ was added to a solution of SPN-OH $(1 \mathrm{~g}$, 2.6mmol) and $\mathrm{Et}_{3} \mathrm{~N}(1 \mathrm{~mL})$ in $\mathrm{CHCl}_{3}$ at $0^{\circ} \mathrm{C}$. Then the mixture was stirred at room temperature for $8 \mathrm{~h}$ and washed with distilled water $(3 \times 50 \mathrm{~mL})$. The collected organic layers were dried over $\mathrm{NaSO}_{4}$, and the chloroform was removed in vacuum to gain the product SPN-Cl $(0.892 \mathrm{~g}, 75 \%)$ after the purification by flash chromatograph $\left(\mathrm{CH}_{2} \mathrm{Cl}_{2}\right.$ : hexane, 1/1, v/v). ${ }^{1} \mathrm{H} \mathrm{NMR}\left(\mathrm{CDCl}_{3}\right) \delta 8.03(\mathrm{~m}, 2 \mathrm{H}), 6.93(\mathrm{~d}, 1 \mathrm{H}, J=12 \mathrm{~Hz}), 6.74(\mathrm{~m}, 3 \mathrm{H})$, 6.59(d, 1H, J=8Hz), 5.92(d, 1H, J=8Hz), 4.3(m, 2H), 4.05(s, 2H), 3.80(s, 3H), 3.5 (m, 1H), $3.4(\mathrm{~m}, 1 \mathrm{H}), 1.2(\mathrm{~s}, 3 \mathrm{H}), 1.1(\mathrm{~s}, 3 \mathrm{H}) .{ }^{13} \mathrm{C} \mathrm{NMR}\left(\mathrm{CDCl}_{3}\right) \delta 166.14,158.38,153.38$, $140.09,139.62,136.37,127.35,124.93,121.76,120.73,117.45,114.50,110.49$, 108.81, 106.003, 105.736, 63.147, 54.91, 51.97, 41.55, 39.66, 24.73, 18.75. MS (EI): 458.1.

Meo Spn-Cl

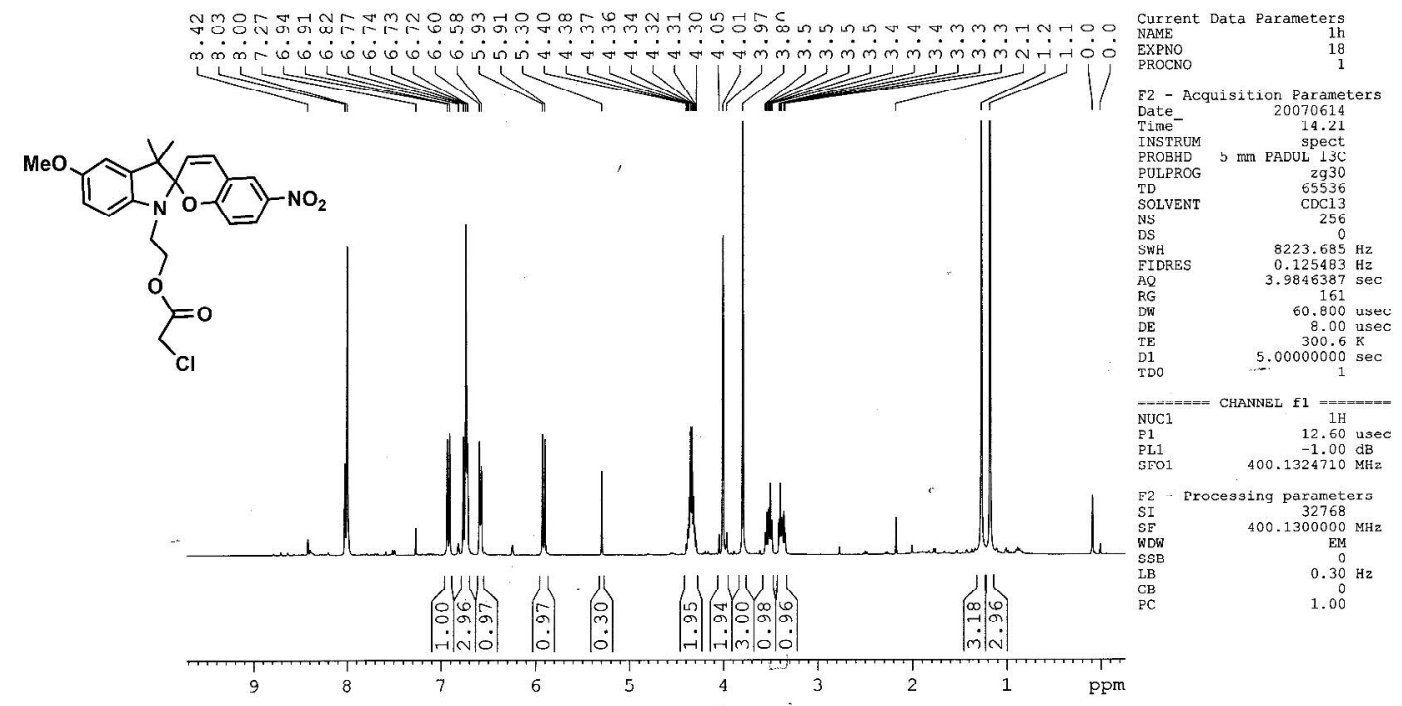




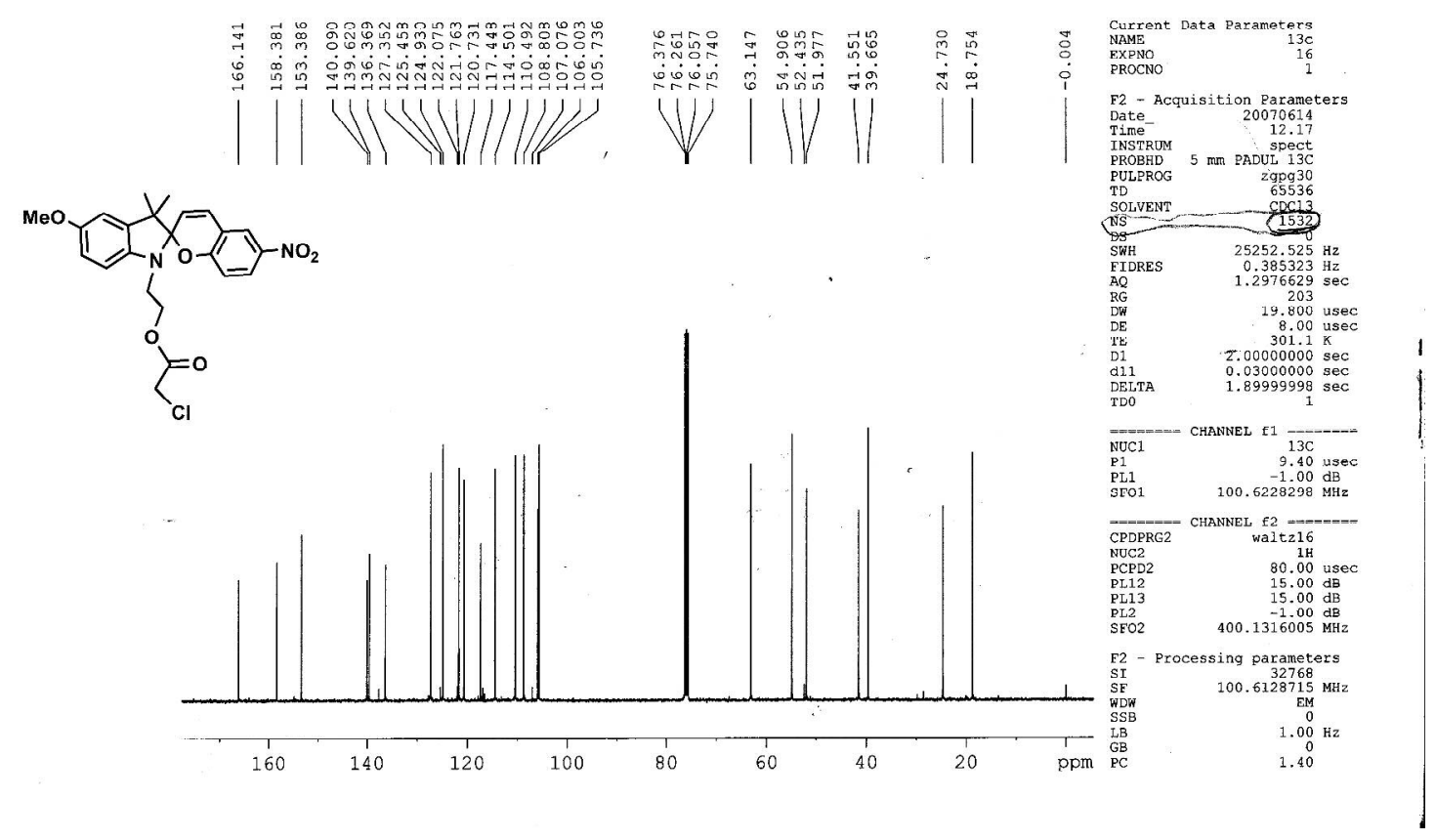




\section{2-(4-tritylphenoxy)acetic acid (2)}

A mixture of 4-tritylphenol $(3.36 \mathrm{~g}, 10 \mathrm{mmol})$ and ethyl 2-bromoacetate $(1.67 \mathrm{~g}, 10 \mathrm{mmol})$ were dissolved in $250 \mathrm{~mL}$ dry acetone and refluxed for 6 hours in the presence of $\mathrm{K}_{2} \mathrm{CO}_{3}(4.14 \mathrm{~g}$, 30mmol) under nitrogen. The mixture was filtered and the solvent was evaporated. The crude product was dissolved in $\mathrm{CH}_{2} \mathrm{Cl}_{2}$ and washed three times with distilled water. The organic solvent was then evaporated off to give a pale solid, which was used directly in the following step without further purification. To the ethanol solution of this pale solid, $10 \mathrm{ml} 50 \% \mathrm{NaOH}$ aqueous solution was added at room temperature. The mixture was stirred for 10 hours followed by the addition of excess hydrochloric acid. Much white appreciate formed with the addition of hydrochloric acid, then it was filtered and washed with distilled water and $\mathrm{CH}_{2} \mathrm{Cl}_{2}$ for several times to give the white solid (2.1g, 53\%). MS (EI): 393(M $\left.{ }^{+}\right) .{ }^{1} \mathrm{H}$ NMR(DMSO-D 6$) \delta 7.258$ (m, 6H), 7.18-7.09(9H), $7.005(\mathrm{~d}, 2 \mathrm{H}, J=9 \mathrm{~Hz}), 6.801(\mathrm{~d}, 2 \mathrm{H}, J=9 \mathrm{~Hz}), 4.59(\mathrm{~s}, 2 \mathrm{H}) .{ }^{13} \mathrm{C}$ NMR(DMSO-D 6 ) $\delta 170.13$, $155.699,146.575,138.768,131.491,130.41,127.609,125.773,113.486,64.548,63.766$.
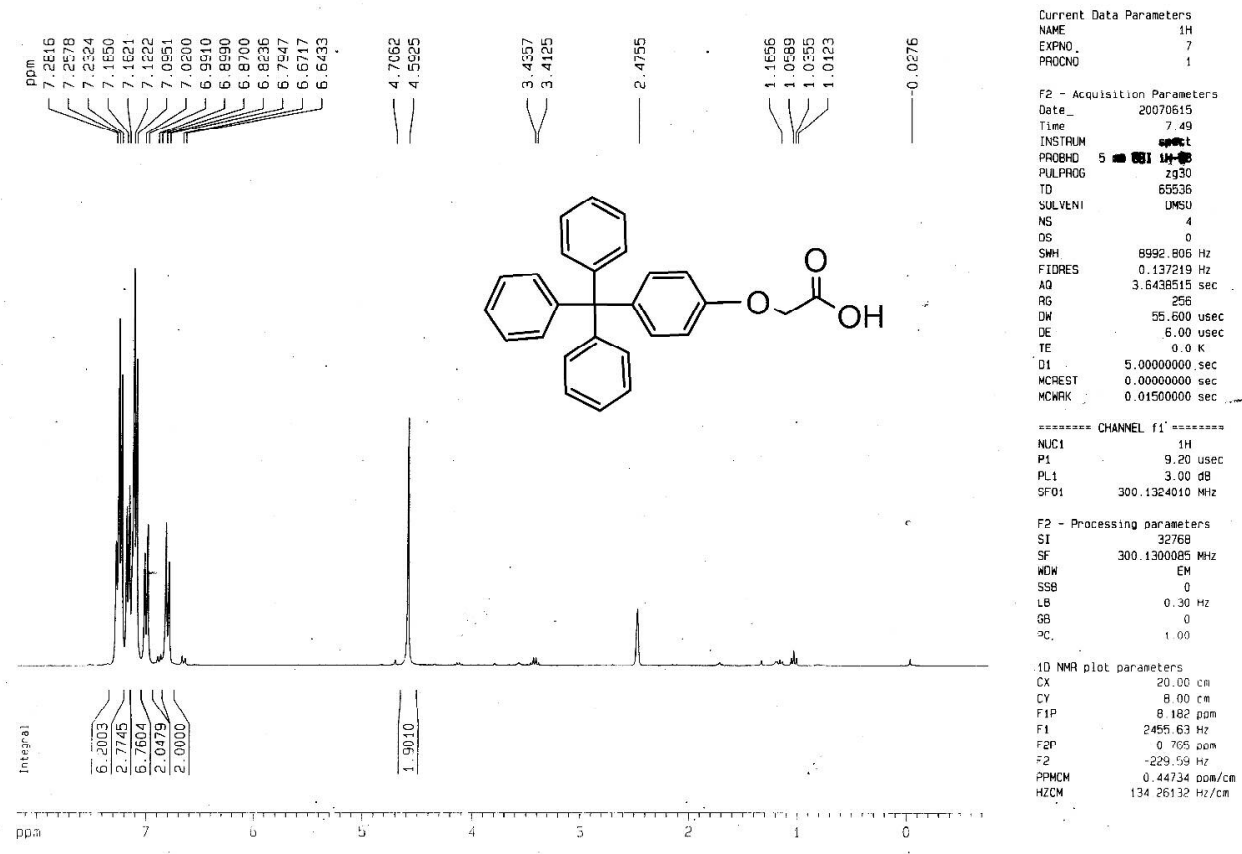

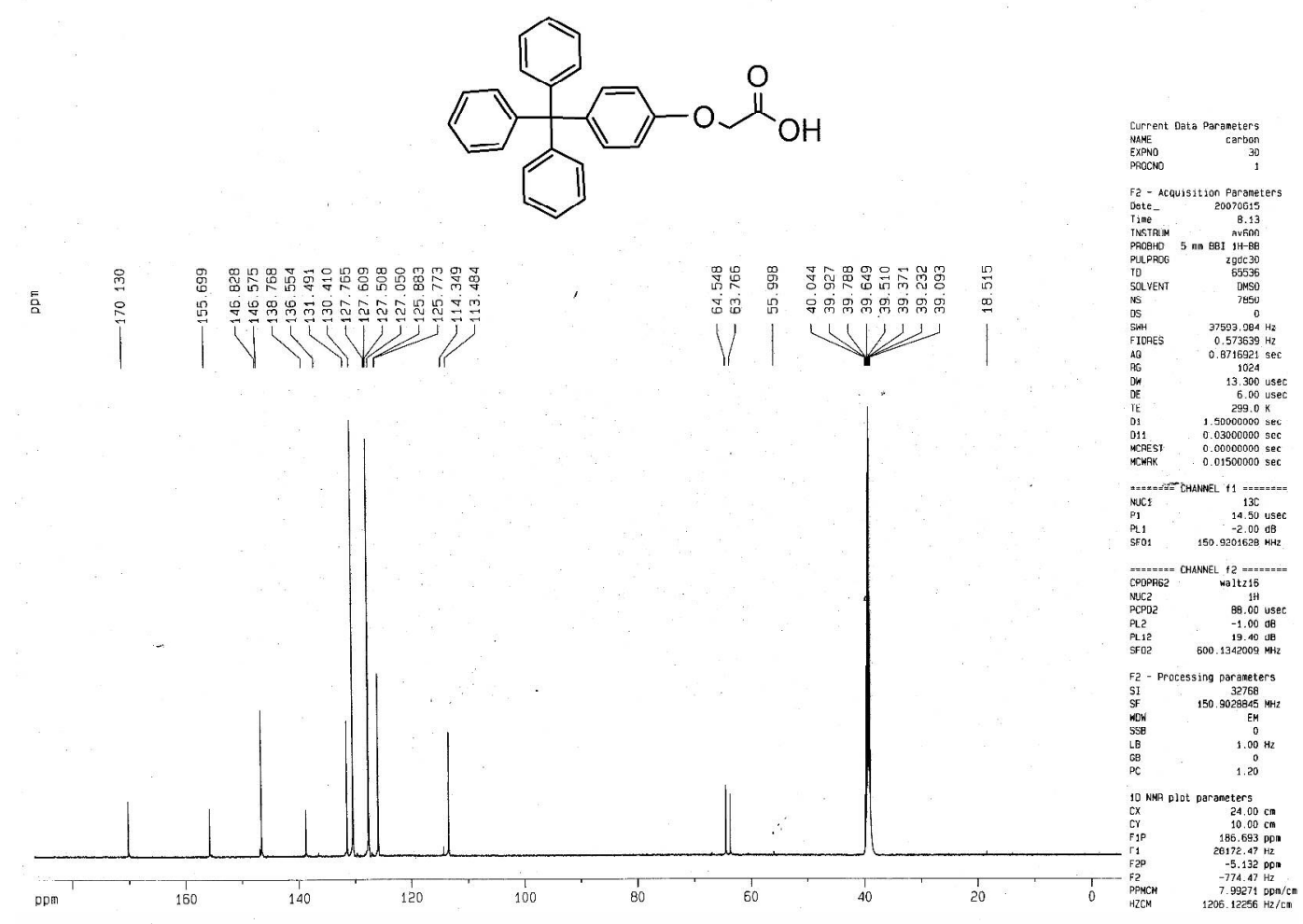


\section{ethyl 2-(2-(2-(4-tritylphenoxy)acetamido)acetamido)acetate (3)}

To a stirred solution of compound $\mathbf{2}(1.56 \mathrm{~g}, 4 \mathrm{mmol})$, ethyl 2-(2-aminoacetamido)acetate hydrochloride (784m g, $4 \mathrm{mmol})$ and DMAP (576 mg, $4.5 \mathrm{mmol})$ in anhydrous $\mathrm{CH}_{2} \mathrm{Cl}_{2}(200 \mathrm{~mL})$ cooled on an ice bath was added EDCI.HCl (955mg, $5 \mathrm{mmol}$ ). After $12 \mathrm{~h}$ the solution was washed with a saturated solution of citric acid $(3 \times 80 \mathrm{~mL})$ and $\mathrm{H}_{2} \mathrm{O}(3 \times 50 \mathrm{~mL})$ and the organic layer dried over anhydrous $\mathrm{Na}_{2} \mathrm{SO}_{4}$, filtered and the filtrate reduced in volume to obtain a white solid. Purification was accomplished by column chromatography on silica with $\mathrm{CH}_{2} \mathrm{Cl}_{2} / \mathrm{CH}_{3} \mathrm{OH}(50 / 1, \mathrm{v} / \mathrm{v})$ to give $3(1.71 \mathrm{~g}, 80 \%) .{ }^{1} \mathrm{H} \mathrm{NMR}\left(\mathrm{CDCl}_{3}\right): \delta 7.37$ (broad, 1H), 7.23-7.12 (m, 17H), 6.789 (d, 2H, J=8.9Hz), $4.51(\mathrm{~s}, 2 \mathrm{H}), 4.18(\mathrm{q}, 2 \mathrm{H}, J=7.14 \mathrm{~Hz})$, $4.08(\mathrm{~d}, 2 \mathrm{H}, J=5.58 \mathrm{~Hz}), 4.02(\mathrm{~d}, 2 \mathrm{H}, J=5.31 \mathrm{~Hz}), 1.25(\mathrm{t}, 3 \mathrm{H}, J=7.16 \mathrm{~Hz}) .{ }^{13} \mathrm{C} \mathrm{NMR}$ $\left(\mathrm{CDCl}_{3}\right): \delta 168.54,168.02,167.6,154.1,145.76,139.7,131.47,131.04,126.468$, 124.94, 112.56, 66.19, 63.32, 60.61, 41.54, 40.32, 13.09. MS (EI): 536.

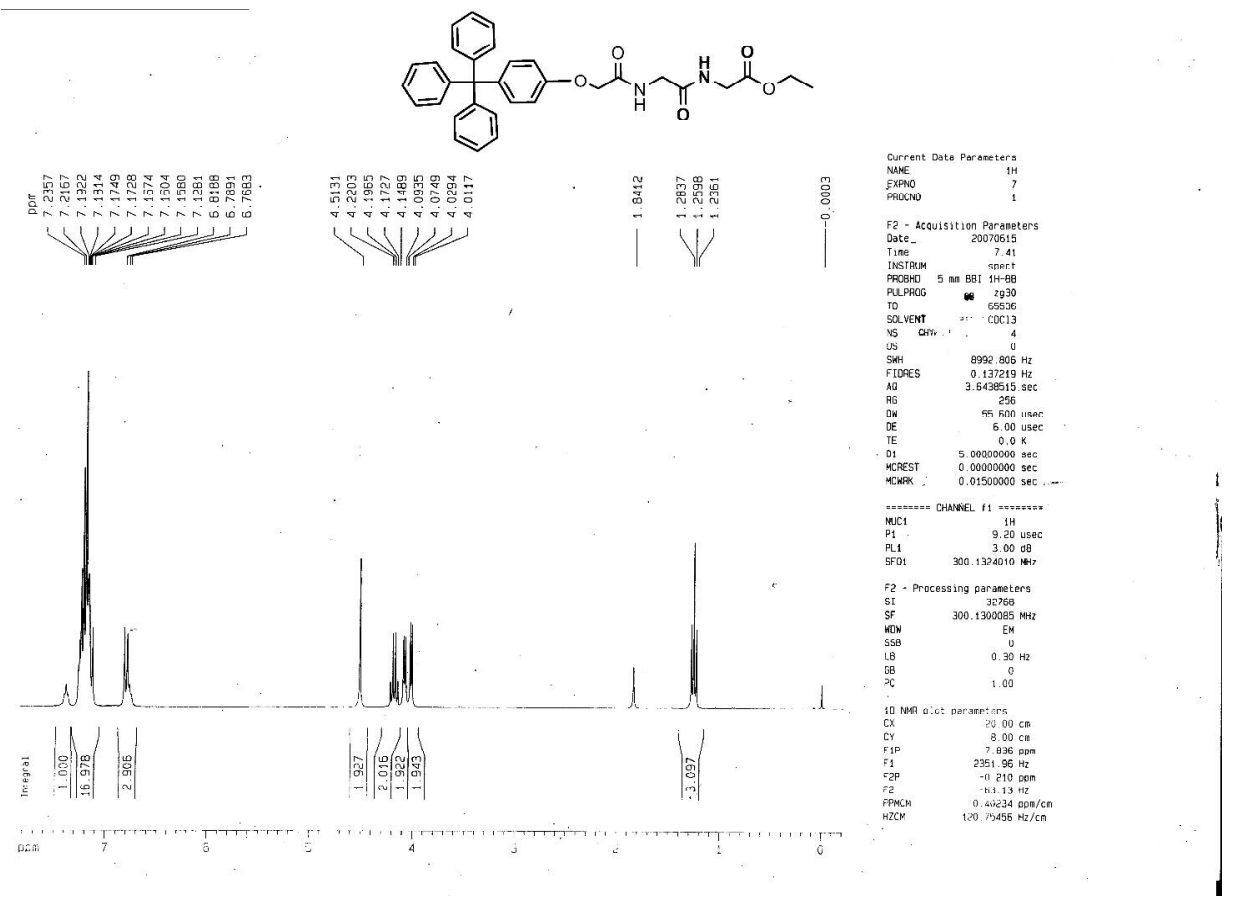




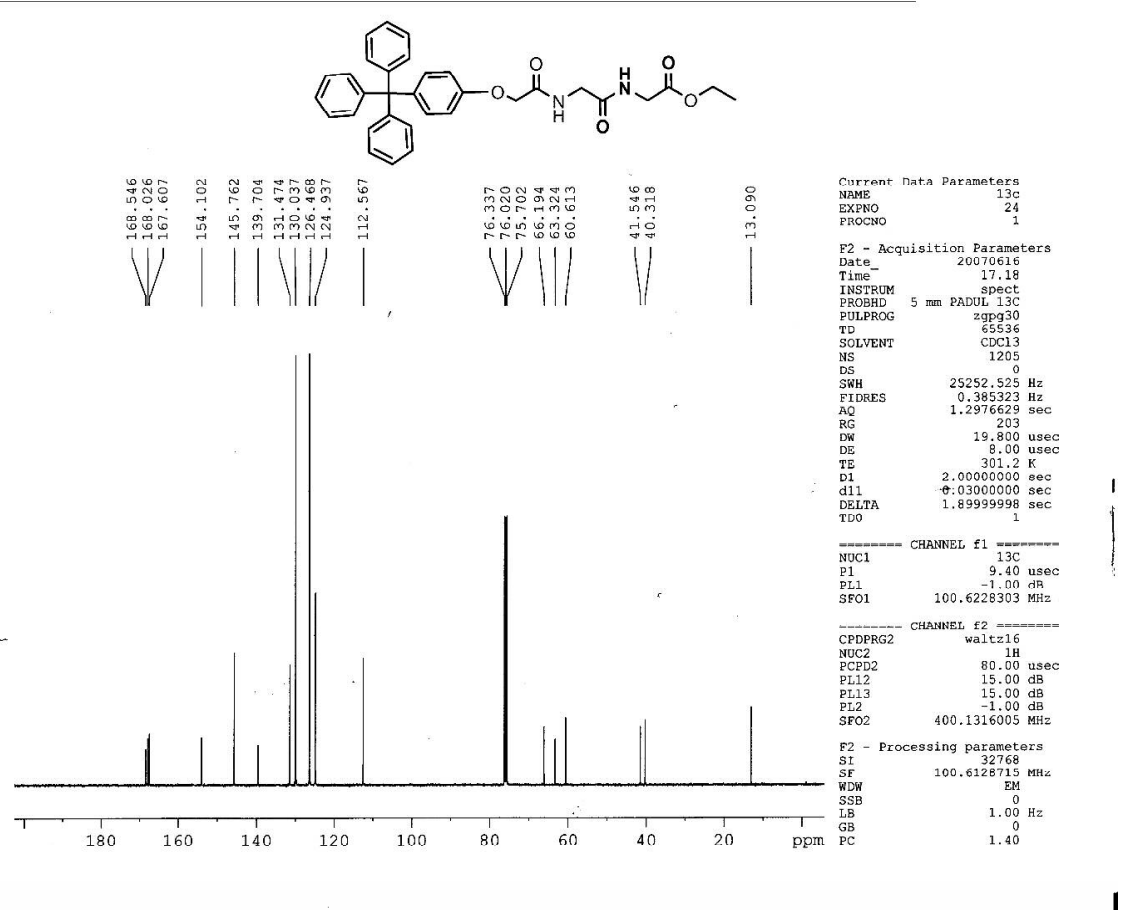




\section{2-(2-(2-(4-tritylphenoxy)acetamido)acetamido)acetic acid (4)}

In a 50-mL flask, compound $3(1.07 \mathrm{~g}, 2 \mathrm{mmol})$ was dissolved in $100 \mathrm{~mL}$ of EtOH/THF (1:1, v:v). $\mathrm{NaOH}$ aquous solution $(5 \mathrm{~mL}, 2 \mathrm{~mol} / \mathrm{L})$ was carefully added under stirring. The reaction mixture was stirred for $12 \mathrm{~h}$ at room temperature. Then, the solvent was removed under reduced pressure, and the residue was redissolved in distilled water. $\mathrm{HCl}$ aquous solution $(10 \mathrm{~mL}, 2 \mathrm{~mol} / \mathrm{L})$ was carefully added under stirring. The reaction mixture was filtered and washed with distilled water for several times. $975 \mathrm{mg}(96 \%)$ product was obtained as a white solid after dehydration. ${ }^{1} \mathrm{HNMR}$ $\left(\right.$ DMSO-D $\left._{6}\right): \delta 8.32(\mathrm{t}, 1 \mathrm{H}, J=5.9 \mathrm{~Hz}), 8.22(\mathrm{t}, 1 \mathrm{H}, J=5.9 \mathrm{~Hz}), 7.31-7.28(\mathrm{~m}, 6 \mathrm{H})$, 7.26-7.13(m 9H), 7.06(d, 2H, J=8.9Hz), 6.93(d, 2H, J=8.9Hz), 4.52(s, 2H), 3.83(d, $2 \mathrm{H}, J=5.9 \mathrm{~Hz}), 3.78(\mathrm{~d}, 2 \mathrm{H}, J=5.9 \mathrm{~Hz}) .{ }^{13} \mathrm{C} \mathrm{NMR}\left(\right.$ DMSO-D $\left._{6}\right): \delta 171.706,169.564$, $168.599,156.19,147.17,139.69,132.18,131.03,128.25,126.53,114.41,67.414,64.399,42.129$, 41.18. MS (EI): 507( $\left.\mathrm{M}^{+}\right)$.
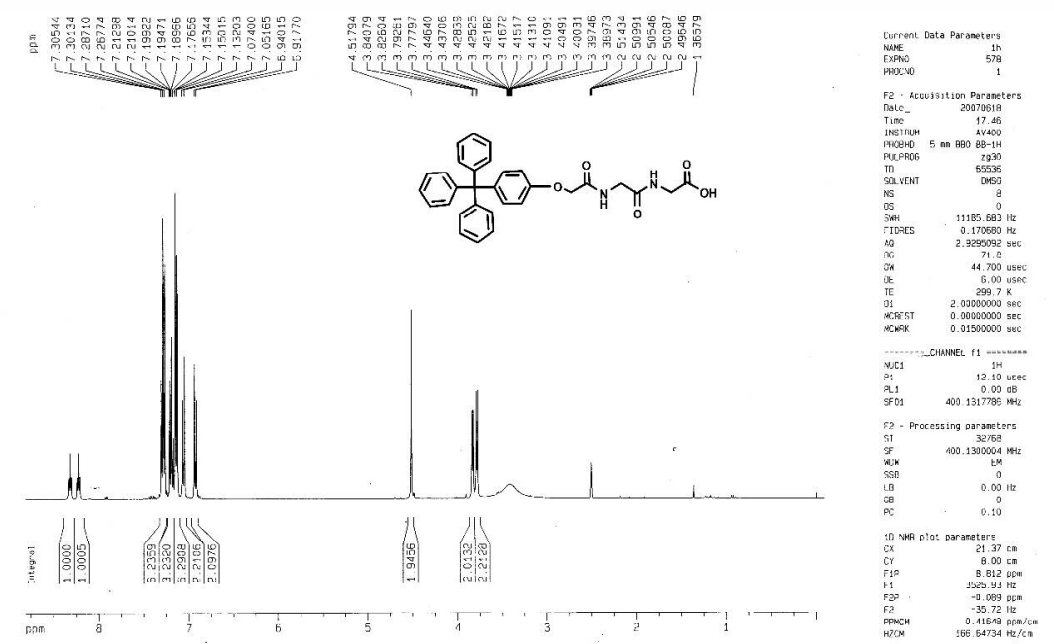


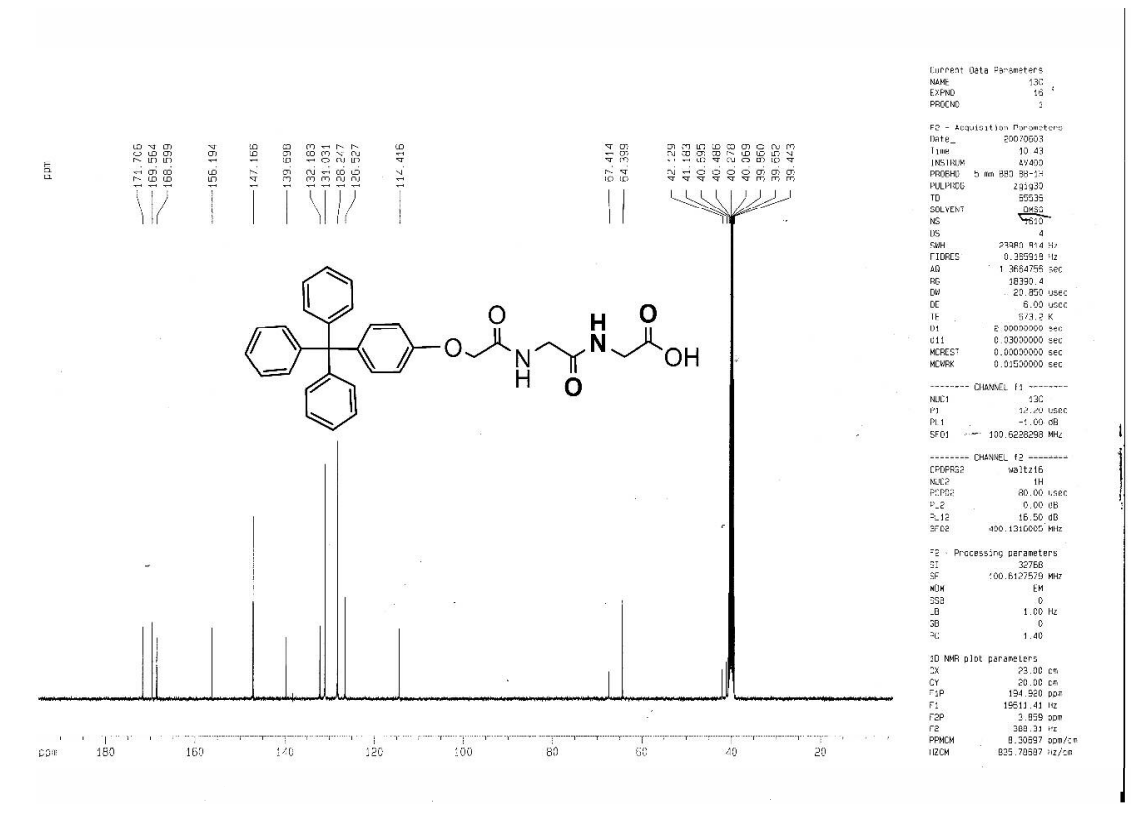




\section{SP-2}

To a stirred solution of $\mathbf{4}(508 \mathrm{mg}, 1 \mathrm{mmol})$ in DMF was added $\mathbf{S P}-\mathbf{C l}(458 \mathrm{mg}, 1 \mathrm{mmol})$ and $\mathrm{K}_{2} \mathrm{CO}_{3}$ (414mg, 3mmol) under nitrogen flux. The mixture was heated to $80^{\circ} \mathrm{C}$ and stirred for 8 hours. Then the solvent was distilled under reduced pressure, and the residue was washed with water and dried with $\mathrm{Na}_{2} \mathrm{SO}_{4}$. Purification was accomplished by column chromatography on silica with $\mathrm{CH}_{2} \mathrm{Cl}_{2} / \mathrm{MeOH}(50 / 1, \mathrm{v} / \mathrm{V})$ to give $\mathbf{S P}-2600 \mathrm{mg}(65 \%) .{ }^{1} \mathrm{H}$ NMR $\left(\mathrm{CD}_{3} \mathrm{CN}-\mathrm{D}_{3}\right): \delta 8.07(\mathrm{~d}, 1 \mathrm{H}$, $J=2.94 \mathrm{~Hz}), \quad 7.98(\mathrm{~d} \times \mathrm{d}, 1 \mathrm{H}, J=8.82 \mathrm{~Hz}, J=3.2 \mathrm{~Hz}), 7.49(\mathrm{t}, 1 \mathrm{H}, J=5.5 \mathrm{~Hz}), 7.28-7.22(\mathrm{~m}, 13 \mathrm{H})$, 7.20-7.16(m, 5H), 7.03(d, 1H, J=10.2Hz), 6.98(t, 1H, J=5.4Hz), 6.88(d, 2H, $J=9 \mathrm{~Hz}), 6.77(\mathrm{~d}, 1 \mathrm{H}$, $J=2.4 \mathrm{~Hz}), 6.72(\mathrm{~d} \times \mathrm{d}, 1 \mathrm{H}, J=8.4 \mathrm{~Hz}, J=3.2 \mathrm{~Hz}), 6.69(\mathrm{~d}, 1 \mathrm{H}, J=9 \mathrm{~Hz}), 6.59(\mathrm{~d}, 1 \mathrm{H}, J=8.4 \mathrm{~Hz}), 5.95(\mathrm{~d}$, $1 \mathrm{H}, J=10.2 \mathrm{~Hz}), 4.57(\mathrm{q}, 2 \mathrm{H}, J=10.2 \mathrm{~Hz}), 4.48(\mathrm{~s}, 2 \mathrm{H}), 4.35-4.30(\mathrm{~m}, 1 \mathrm{H}), 4.22-4.17(\mathrm{~m}, 1 \mathrm{H}), 3.97(\mathrm{~d}$, $2 \mathrm{H}, J=6.6 \mathrm{~Hz}), 3.89$ (d, $2 \mathrm{H}, J=6.0 \mathrm{~Hz}), 3.73(\mathrm{~s}, 3 \mathrm{H}), 3.48-3.42(\mathrm{~m}, 1 \mathrm{H}), 3.33-3.27(\mathrm{~m}, 1 \mathrm{H}), 1.22(\mathrm{~s}$, $3 \mathrm{H}), 1.12(\mathrm{~s}, 3 \mathrm{H}) .{ }^{13} \mathrm{C} \mathrm{NMR}\left(\mathrm{CD}_{3} \mathrm{Cl}\right) \delta 168.994,167.196,162.585,159.383,155.189,154.358$, $146.799,141.039,140.527,137.382,132.379,130.99,128.46,127.48,126.05,122.83,121.58$, $118.50,115.47,109.75,106.99,106.74,113.59,111.53,67.184,64.311,63.477,60.99,55.888$, 53.57, 52.94, 42.559, 42.336, 40.9, 36.438, 31.366, 25.717, 19.725. MS (MALDI-TOF): 930, 953(SP-2 +Na).

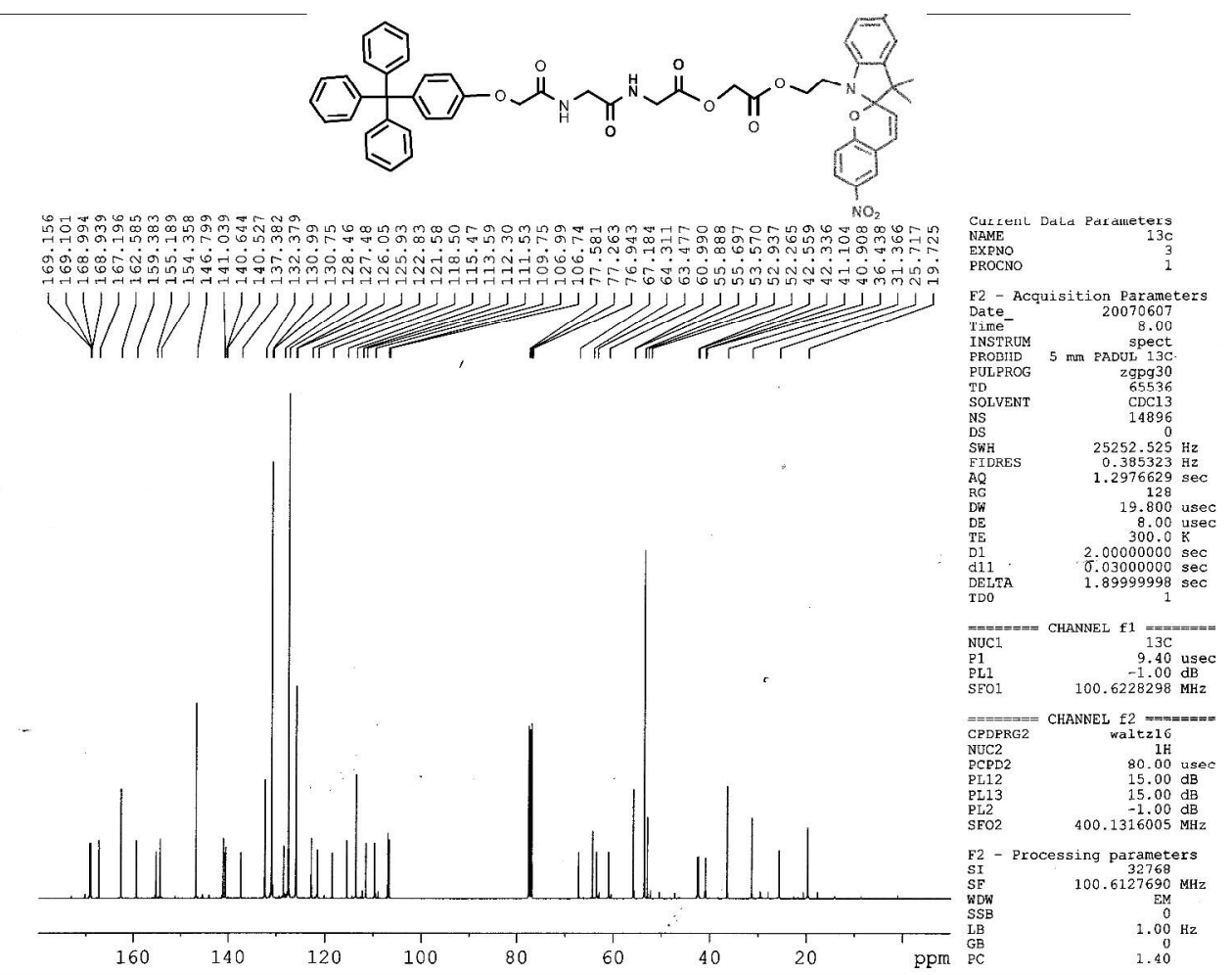




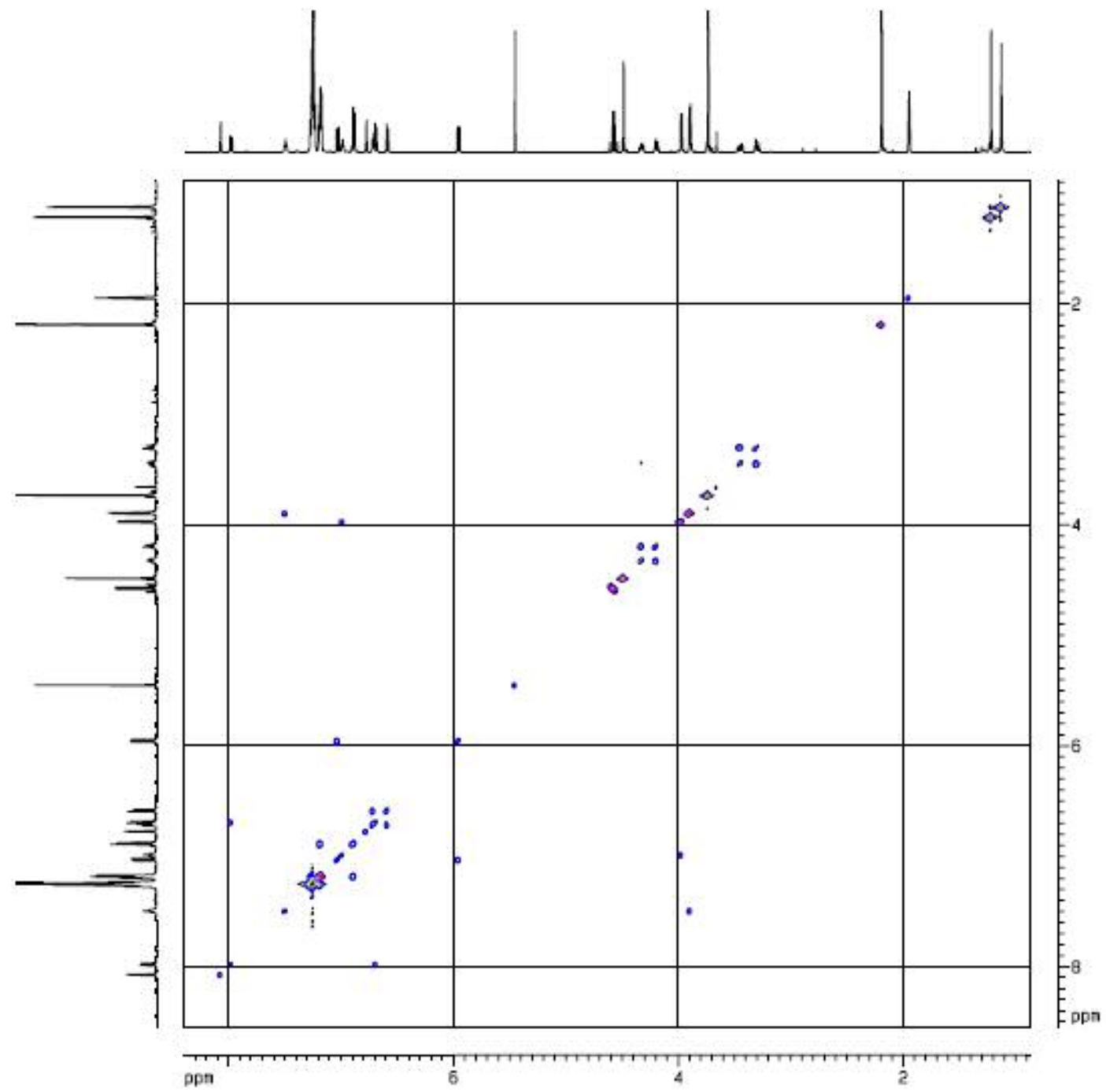




\section{SP-1}

To a solution of $0.186 \mathrm{~g}(0.2 \mathrm{mmol})$ of SP-2 in $200 \mathrm{~mL}$ of $\mathrm{CH}_{2} \mathrm{Cl}_{2}$ and $\mathrm{Et}_{3} \mathrm{~N}$ (exc.) were added simultaneously solutions of $0.404 \mathrm{~g}$ ( $2 \mathrm{mmol})$ of 3,5-pyridinedicarbonyl dichloride in $60 \mathrm{~mL}$ of $\mathrm{CH}_{2} \mathrm{Cl}_{2}$ and $0.272 \mathrm{~g}(2 \mathrm{mmol})$ of $\mathrm{p}$-xylylenediamine in $60 \mathrm{~mL}$ of $\mathrm{CH}_{2} \mathrm{Cl}_{3}$ over a period of $2 \mathrm{hrs}$. The mixture was stirred for 4 hours and then filtrated. The filtrate was concentrated and purified by flash chromatography (silica gel, $5 \% \mathrm{MeOH}$ in $\mathrm{CH}_{2} \mathrm{Cl}_{2}$ ) to obtain $58 \mathrm{mg}(20 \%)$ of the title compound as a grey solid.

${ }^{1} \mathrm{HNMR}\left(\mathrm{CD}_{3} \mathrm{CN}-\mathrm{D}_{3}\right): \delta 8.385(\mathrm{~s}, 2 \mathrm{H}), 8.028-7.988(\mathrm{~m}, 5 \mathrm{H}), 7.953(\mathrm{~d} \times \mathrm{d}, 1 \mathrm{H}, J=9 \mathrm{~Hz}$, $J=3 \mathrm{~Hz}), 7.659(\mathrm{~m}, 4 \mathrm{H}), 7.518(\mathrm{t}, 2 \mathrm{H}, J=7.8), 7.499(\mathrm{t}, 1 \mathrm{H}, J=5.4), 7.264(\mathrm{~m}, 7 \mathrm{H})$, 7.179(m, 10H), 7.143(s, 8H), 6.970(d, 1H, J=11.4Hz), 6.938(d, 3H, J=9.6Hz), 6.747(d, 1H, $J=2.4 \mathrm{~Hz}), 6.674(\mathrm{~d}, 2 \mathrm{H}, J=9 \mathrm{~Hz}), 6.501(\mathrm{~d}, 1 \mathrm{H}, J=8.4 \mathrm{~Hz}), 6.413(\mathrm{~d}, 2 \mathrm{H}$, $J=9.6 \mathrm{~Hz}), 5.875(\mathrm{~d}, 1 \mathrm{H}, J=11.2 \mathrm{~Hz}), 4.42-4.37(\mathrm{~m}, 9 \mathrm{H}), 4.19(\mathrm{~m}, 1 \mathrm{H}), 4.09(\mathrm{~m}, 1 \mathrm{H})$, 4.07(s, 2H), 3.807(d, 2H, J=5.4Hz), 3.72(s, 3H),3.389-3.31(m, 1H), 3.235-3.108(m, $1 \mathrm{H}), 2.817(\mathrm{~d}, 2 \mathrm{H}, J=4.8 \mathrm{~Hz}), 1.188(3,3 \mathrm{H}), 1.08(\mathrm{~s}, 3 \mathrm{H}) .{ }^{13} \mathrm{CNMR}\left(\mathrm{CD}_{3} \mathrm{CN}\right)$ 169.625, $168.923,169.23,166.94,166.64,159.37,154.36,154.14,146.63,141.32,140.98$, 140.57, 137.46, 133.91, 131.457, 130.96, 129.036, 127.56, 125.98, 118.37, 106.911, 64.27, 53.45, 52.96, 44.095. MS (MALDI-TOF): 1463.6. 

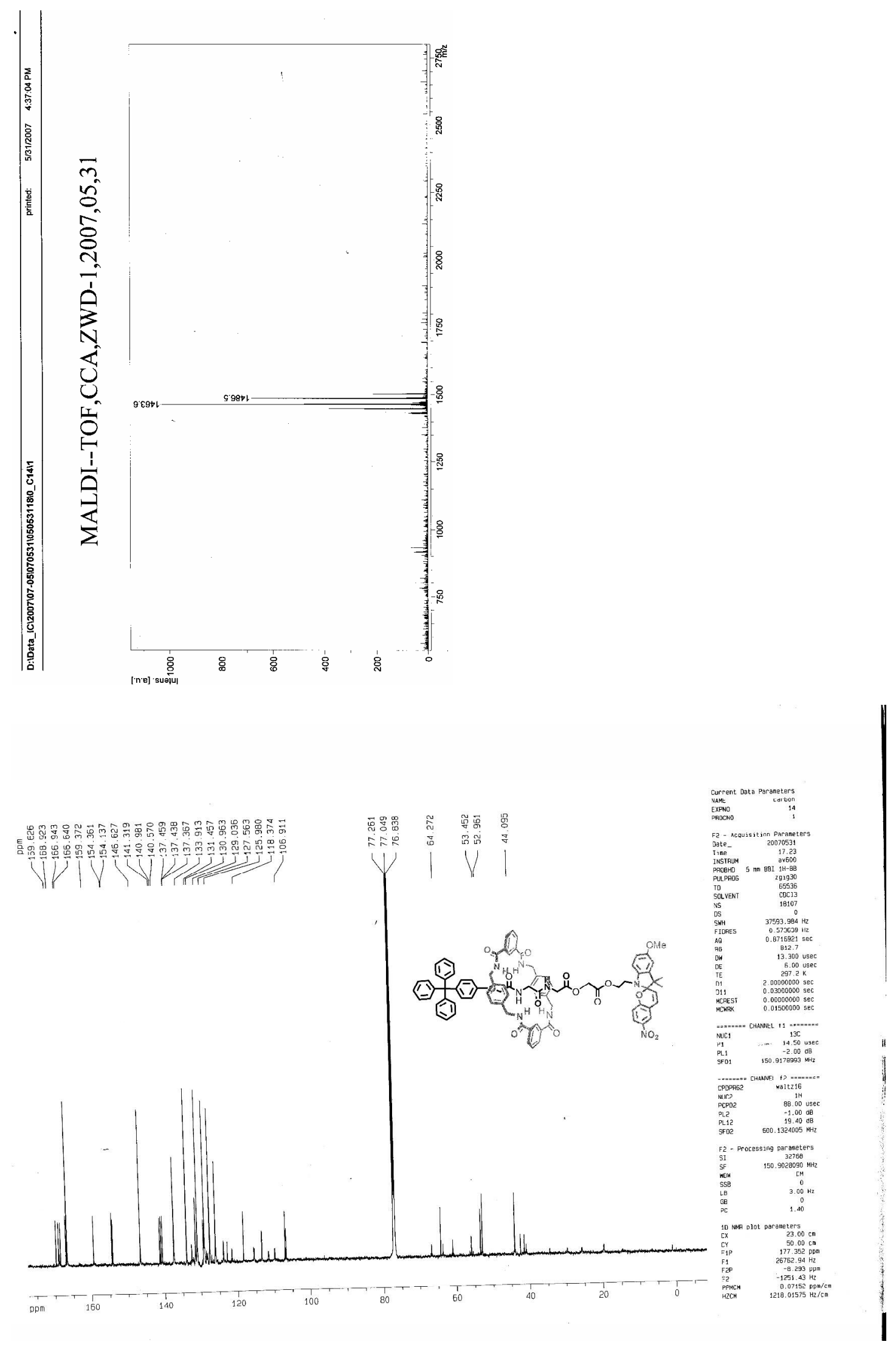


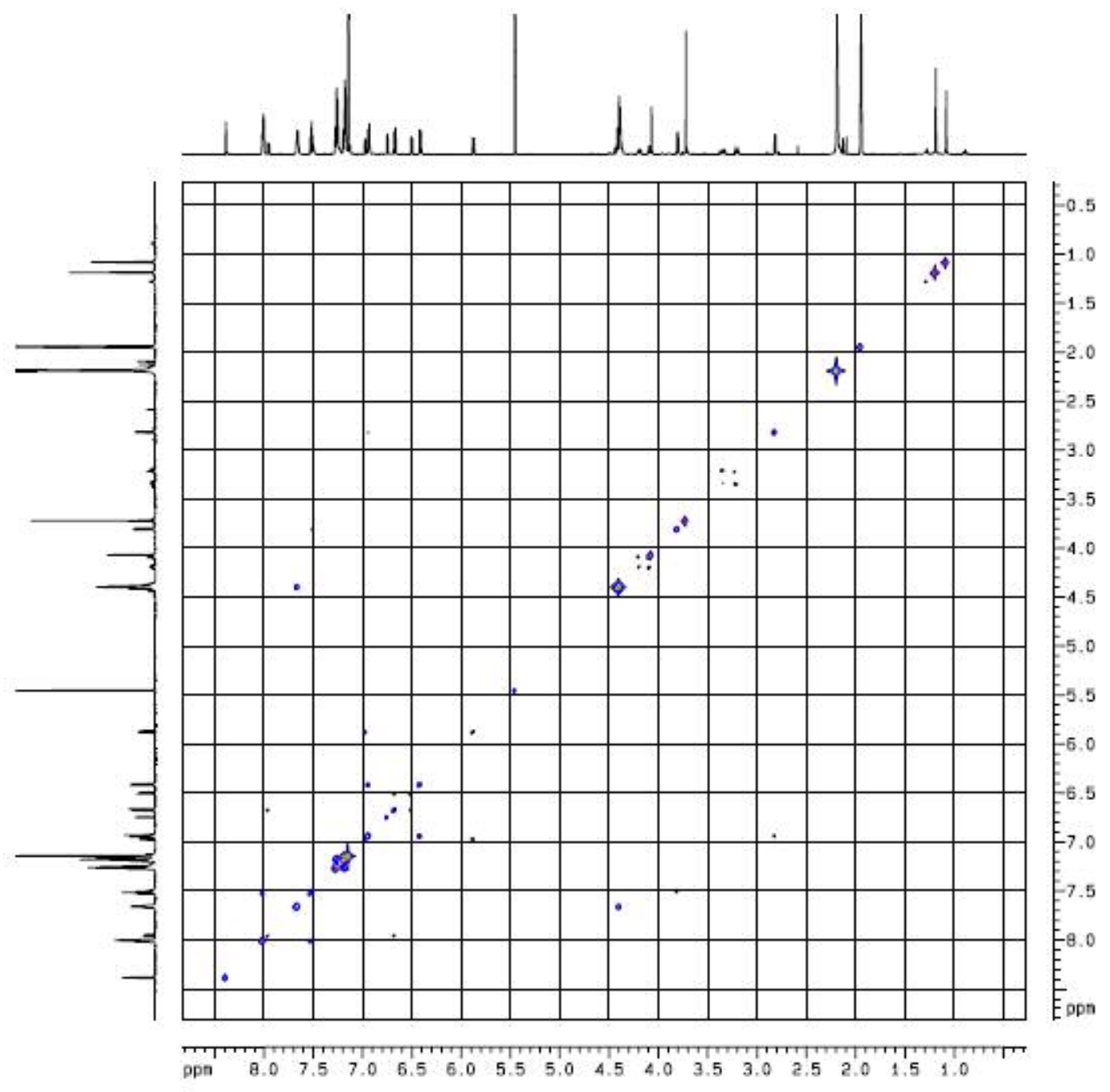

- 18 - 
ME-1

ME-1 was gained from the irradiation of SP-1 with $365 \mathrm{~nm}$ UV light for $3 \mathrm{~min}$ at room temperature. The opened structure ME-1 is just about $26 \%$ of the total isomers according to the analysis of this ${ }^{1} \mathrm{H}$ NMR spectrum.
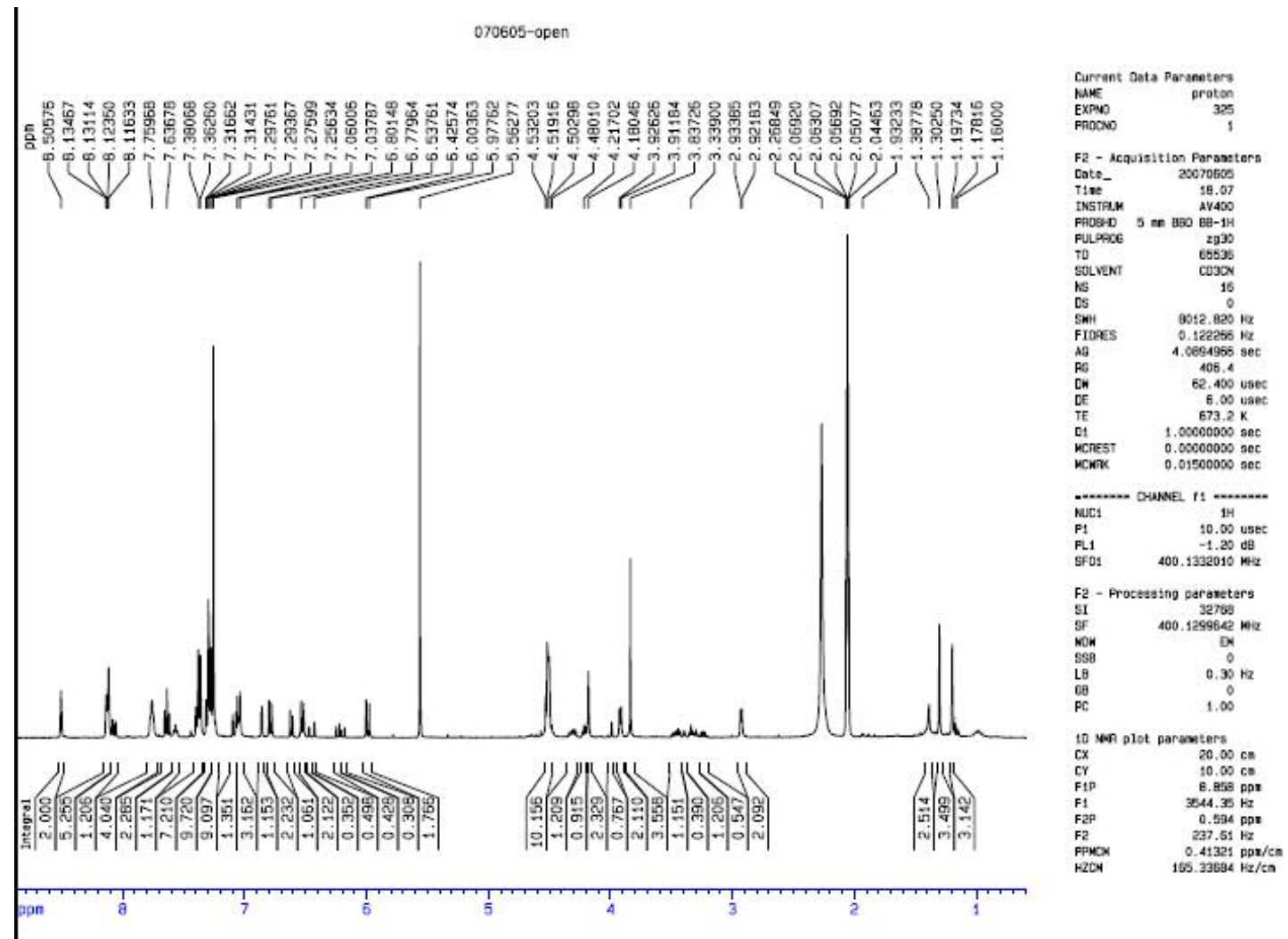

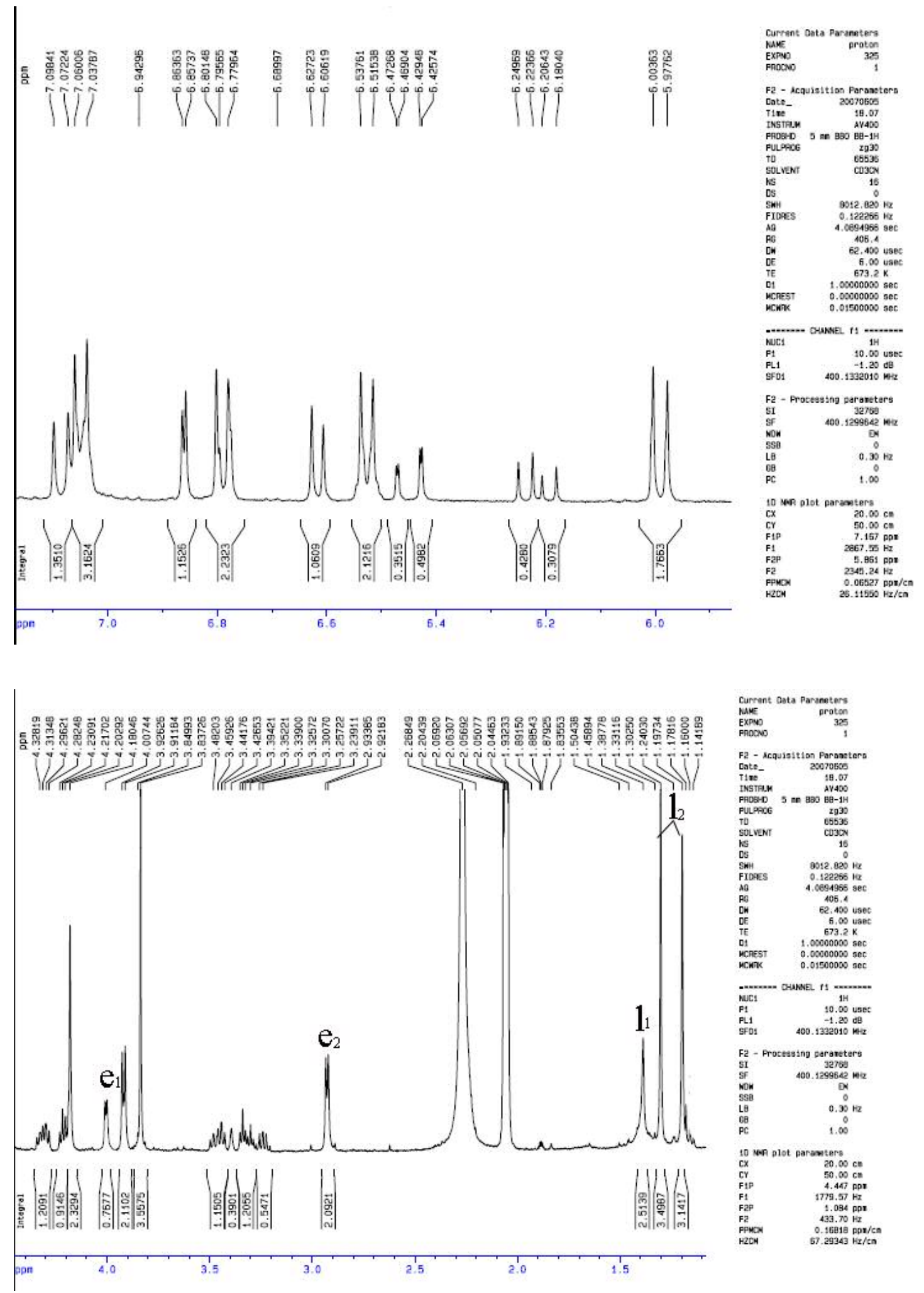

The signals of $e_{1}$ and $l_{1}$ come from the opened form ME-1, while the $e_{2}$ and $l_{2}$ come from the closed form $\mathbf{S P - 1} \mathrm{e}_{1} / \mathrm{e}_{2}=0.36,1_{1} / \mathrm{l}_{2}=0.37$. 


\section{§5. Kinetic Studies}

In the dark, the rate of switching from ME to SP is given by equation (1). ${ }^{[1]}$ [ME1] and [ME2] are concentrations of ME1 and ME2, respectively. $k_{1}$ and $k_{2}$ are rate constants for two isomerization reactions. $t_{1}$ and $t_{2}$ are reaction times. [ME] is related to the absorption (A), measured at a certain wavelength. The ratio of $k_{1} / k_{2}$ was calculated from the equation (2) which is deduced from equation (1).

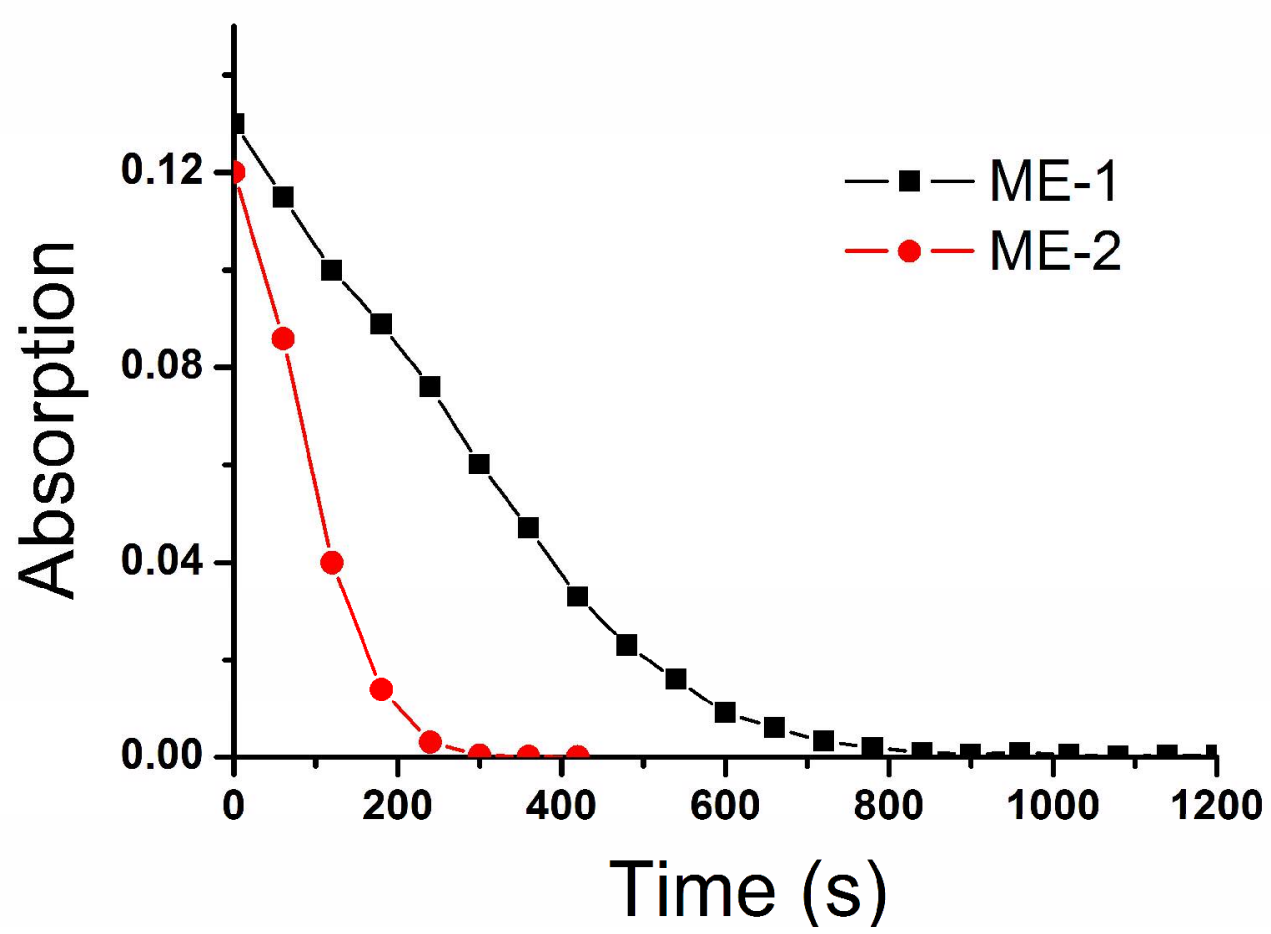

The plot of the absorption spectra from ME-1 and ME-2 at 569nm against time in the dark. $\left(5 \times 10^{-5} \mathrm{M}, \mathrm{CH}_{3} \mathrm{CN}, 25^{0} \mathrm{C}\right)$

$$
\begin{aligned}
& \ln [\mathrm{ME}]=-k \mathrm{t}+\ln \left[\mathrm{ME}_{0}\right] \\
& -k \mathrm{t}=\ln [\mathrm{ME}]-\ln \left[\mathrm{ME}_{0}\right] \\
& k_{1} / k_{2}=\left(\ln [\mathrm{ME} 1]-\ln \left[\mathrm{ME} 1_{0}\right]\right) /\left(\ln [\mathrm{ME} 2]-\ln \left[\mathrm{ME} 2_{0}\right]\right) \times\left(\mathrm{t}_{2} / \mathrm{t}_{1}\right) \\
& k_{1} / k_{2}=0.167
\end{aligned}
$$

\section{§6. Reference.}

(1) F. M. Raymo, S. Giordani J. Am. Chem. Soc. 2001, 123, 4651-4652. mol L $\mathrm{L}^{-1}$ 